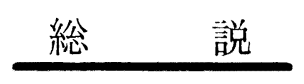

石 油 発 酵
中 原 忠 篤
東京大学農学部農芸化学科 (東京都文京区弥生: 1-1-1)

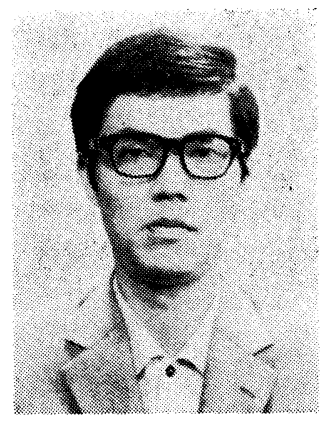

\title{
Petroleum Fermentation
}

\author{
Tadaatsu Nakahara \\ Department of Agricultural Chemistry, Faculty of Agriculture, University of Tokyo \\ (1-1-1, Yayoi, Bunkyo-ku, Tokyo)
}

\section{1 はじめに}

石油発酵といら言葉は言葉の使い方の善悪は別とし て, 石油系炭化水素および広く石油化学製品を原料とす る発酵といら意味で使われている。本小文でも，これに 従って打も湠化水素を原料とする発酵についてすでに 明らかにされてきたこととこれからの問題点について述 べてみたいと思う。炭化水素と微生物のかかわり合いは, 19 世紀末にさかのぼるが, 微生物が炭化水素を炭素源 として利用することを明確にしたのは Söhngen による メタン資化性菌の分離であった。その後, 多くの炭化水 素資化性菌（炭化水素を炭素源として利用し生育する微 生物) が見いだされ，多くの情報が蓄積されてきた。し かしながら，これらの研究が応用的な研究に結びつくに は, 1963 年 Société Français de Pétrole BP の

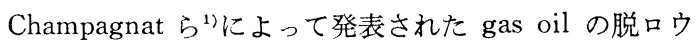
と同時に微生物菌体を製造するといら研究を待たねばな らなかった。これを契機にして炭化水素を菌体製造の原 料にしようといら試みが世界各国において開始されるこ とになった。これは当時から憂慮されていた世界の食糧 危機特にタンパク質不足を克服する手段として多くの 人々の注目を集め, 非常に魅力的な研究テーマとなっ た。日本に扔いても同様に, 大学, 公立研究機関, 民間 企業において精力的な研究が行なわれ，炭化水素を原料 とする菌体の製造は企業化の寸前までいったのである。 しかしながら御承知のように安全性の問題で日本におけ る企業化はストップして現在に至っている。食飼料の安 全性に関する問題は非常にむずかしい問題であるが根本 的な問題であるので, 充分な科学的検討を行なら必要が ある。微生物利用学にたずさわる著者としては, 安全性 の問題が解決されて, 微生物菌体が飼料あるいは食糧の 給源に利用され，世界の食糧危機の解決策の一助となる
ことを期待したい。

以上述べたように, 石油発酵においては微生物菌体に 関する研究が世界的な流れであった。一方日本において は, 微生物菌体の製造に加えて炭化水素を各種の代謝生 物を製造するための原料にしようという意識が強く, し たがって石油発酵は従来の糖質を原料とする発酵（糖質 発酵) に対する原料転換といら観点では握されている。 このことは日本における石油発酵の研究を多彩なものに した。すなわち, アミノ酸, 核酸, ビタミン, 抗生物 質, 酵素の生産などに(いずれも糖質を原料として発酵 生産が行なわれているが)，炭化水素を利用することが 試みられている。

原料䩓換の対象となる原料の備えるべき条件として は, (1) 微生物によって利用されやすいこと, (2) 安価で あること，(3) 供給が安定していることなどがあげられ るが，食飼料を目的とする場合さらに重要なのは (4) 毒 性がないかあるいは製品に毒性が残らないことである。 鎖状炭化水素の場合, (1) (3)の条件は良く満足するもの の (4)の条件にいくらか問題があるといら指摘がなされ ている。これは原料中に微量混在する多環芳香族物質の 問題で, この点についての議論は別の機会に譲りたい。

次に原料転換という立場からでなく, 原料の特徵を発 酵生産に利用しょうといら考え方がある。

たとえば，鎖状炭化水素をとりあげると，鎖状炭化水 素はまずメチレン鎖の末端が酸化されて対応するカルボ ン酸が生成してくる。これらのカルボン酸は糖質から生 産させることは困難であり, 原料に対忘した特殊な生産 物であるといえよう。また各種芳香族炭化水素からはそ れぞれ異なった代謝中間体が生成してくるので, これも また原料の特徵を生かした利用法であり, この分野の研 究には大きな期待が寄せられている。

以上は石油発酵を応用的な観点から見たものである 
が，基礎的研究の対象上しても不油発酵は興味ある問題 を提供する。たとえば，短鎖の炭化水素を原料とする と, それはガス状であるので, ガス発酵といら研究分野 が生じる（技術的には好父培養における酸素の供給問題 と同榢に取り扱われる)。舆鎖の炭化水素を原料とする と, これらは水不溶性であるので, 従来の水溶性の糖質 を原料とする発酵と異なる種々の問題が生じる。一般に 微生物は水層中で生育するから, 水不溶性の炭化水素が いかにして微生物にとり込まれ代謝されていくか非常に 興味ある問題である。また炭化水素は分子巾に膰素原子 を含まないので，菌体やその他の代謝生産物を生成する ために必要な酸素量は糖質発䤀よりはるかに多い。

著者らの研究グループは湠化水素の微生物への取り込 みについて重点的に研究しているので, 炭化水素の酸化 㧍よび代謝, 発醭生産物などに関し述べた後, 本閭題に つきいくらか子れたいと思う。

石油発酵汇関する成眥としては「石油発醳」”，「発酵

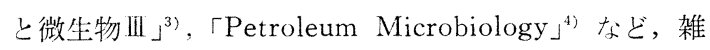
誌としては「石油と微生物」(石油醴酵研”究会発行) があ り，その他多くのすぐれた総説が菖かれている。

\section{2 炭化水素の代謝}

\section{$2 \cdot 1$ 鎖状炭化水素の酸化}

\section{$2 \cdot 1 \cdot 1 \quad$ n-パラフィン}

n-パラフィンは図-1 に示すように, 通常 terminal oxidation を受け，アルコール，アルデヒドを経て脂肪 酸となり，ATP, CoA の関与により acetyl CoA が 生成し, ついで $\beta$ 位置の脱水秦による $\beta$ 酸化がおき, $\mathrm{C}_{2}$ unit が acetyl CoA としてとれて鎖が短くなって 行く。この acetyl CoA は TCA 回路 (tricarboxylic acid cycle) に入り，さらに酸化されて最終的には炭酸 ガスと水になるが，この間にエネルギーを獲得したり菌

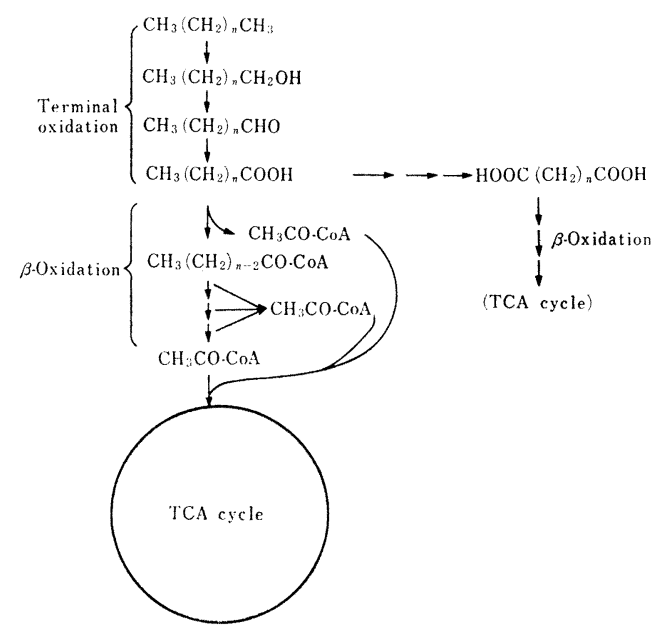

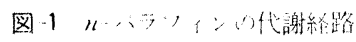

体成分生合成のための代謝け留体が生成する。

terminal oxidation には monoterminal oxdiation, diterminal oxidation および subterminal oxidation がある。多くの微生物では monoterminal oxidation によりモノカルボン朘が生じ， $\beta$ 凌化を受け朘化されて いく経路が，主絟路であろうと考えられているが， diterminal oxidation もしばしば見受けられ，特にCandid $a$ 属の酵母では $\beta$ 酸化経路を細くすることによりジ

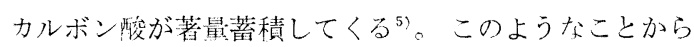
diterminal oxidation も微生物比とって重要な爷応であ ると考えられる。本文応は酵母だけでなく細菌（たとえ ば Corynebacterium ${ }^{6}$ やPseudomonas $\left.{ }^{7}\right)$ やカビ (た

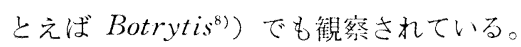

subterminal oxidation の例は少なく, Pseudomonas methanica ${ }^{9}$, Mycobacterium smegmatis (1) $^{10}$ あいは Brevibacterium $\mathrm{s}^{111}$ などで知られている。本友态は 図-2に示すように《位㯰の炭素が軗化されケトン化合 物ができる反応であるが, 多くの莂会, 短鎖の炭化水素 を基質にしたときに見いだされている。既鎖炭化水素を 基質にしたときの例としては，Arthrobacter 属の菌が ペプトンあるいは酵母エキスの伱在下で $n$-へキサデカ ンから 2-, 3-, 4-ヘキ少デカノンを生成したという報告 がある ${ }^{13)}$ 。

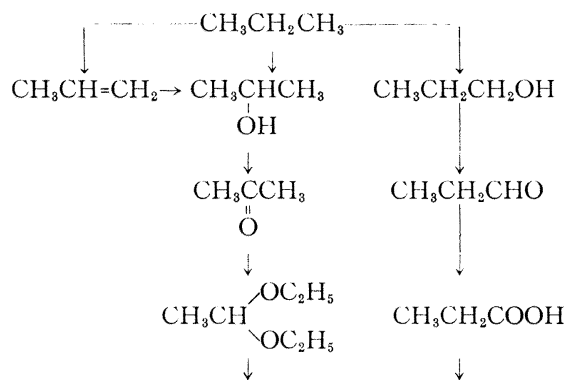

図-2 Mycobacterium によるプロバンの酸化2)

$2 \cdot 1 \cdot 2$ イソパラフィンの酸化

イソパラフィンは $n$-パラフィンに比較して微生物に より酸化されにくい。末端に長い直鎖をもつものは比較 的酸化されやすいが，側鎖の多いものは非常に酸化され にくいとされている。イソパラフィンを最もよく利用で きる菌としては Nocardia が知られ, 本菌はへプタメ チルノナン，スクロレン (2, 6, 10,15, 19，23-へキサメ チルテトラデカン）やプリスタン（2, 6, 10, 14-テトラ メチルペンタデカン) なども利用できる。

$2 \cdot 1 \cdot 3$ オレフィン

オレフィンの酸化経路はパラフィンの場合ほど明らか にされていない。これまでの研究は末端に二重結合のあ るムーオレフィンの酸化に集中している。Klug ら ${ }^{14)}$ は, Candida lipolvtica を用い, めーオレフィンの酸化を検 封し図ー3に示寸上うに一つの経路を推定した 


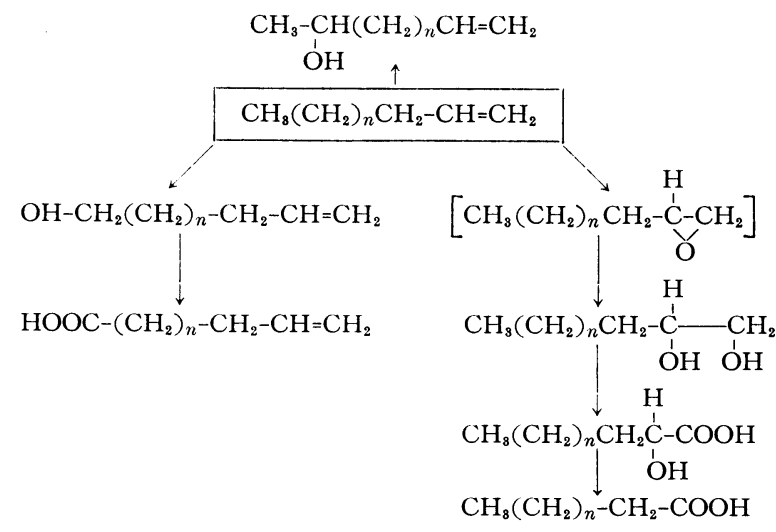

図-3 Candida lipolytica による $\alpha$-オレフィンの酸化 ${ }^{16)}$
(1) メチル基の酸化

(2) 二重結合の酸化

(3) subterminal oxidation

\section{$2 \cdot 2$ 鎖状炭化水素の初発酸化の機構}

炭化水素の初発酸化は次の酸化型式によって行なわれ る。

(1) Monoxygenase による酸素添加反応 (oxygenation)

$\mathrm{R}-\mathrm{CH}_{2}-\mathrm{CH}_{3}+\mathrm{O}_{2}+$ 還元型補酵素

$\rightarrow \mathrm{R}-\mathrm{CH}_{2}-\mathrm{CH}_{2} \mathrm{OH}+\mathrm{H}_{2} \mathrm{O}+$ 酸化型補酵絜

生体における oxygenation は早石らによって最初に 発見されたもので，このときの基質は芳香族化合物であ った。oxygenation に関与する酵素は Oxygenase と 称され, Monoxygenase と Dioxygenase がある。現 在までに多くの Oxygenase が単離精製され, それらの 反応機構が詳細に検討されつつあるが，鎖状炭化水素の 酸化に関与する Oxygenase の研究はまだ緒についだば かりで不明な点が多い。

Peterson ${ }^{15)}$, Kusunose $ら^{16)}$ はPseudomonas oleovorans および P. desmoly. tica を用い, 炭化水素からアルコール を生成することのできる無細胞抽出液を 得て検封した結果, $n$-パラフィンの水酸 化と電子伝達系との 関連を 図-4 のよう に推定した。

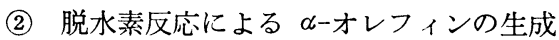
(dehydrogenation)

$$
\mathrm{R}-\mathrm{CH}_{2}-\mathrm{CH}_{3}+\mathrm{NAD}^{+}
$$

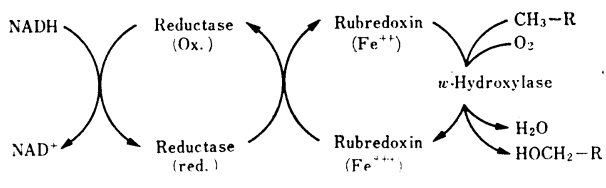

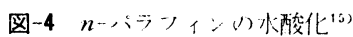

$$
\begin{gathered}
\rightarrow \mathrm{R}-\mathrm{CH}=\mathrm{CH}_{2}+\mathrm{NADH}+\mathrm{H}^{+} \\
\mathrm{R}-\mathrm{CH}=\mathrm{CH}_{2}+\mathrm{H}_{2} \mathrm{O} \rightarrow \mathrm{R}-\mathrm{CH}_{2} \mathrm{CH}_{2} \mathrm{OH}
\end{gathered}
$$

本反応は Azoulay ら ${ }^{17}$ および飯塚ら ${ }^{18)}$ にり， P. aeruginosa, Candida tropicalis および $C$. rugosa を用いて実証されたもので，補酵素として NAD が必要である。脱水素反応であるから最初の 生成物は $\alpha$-オレフィンであり，次に加水されてア ルコールが生成してくる。したがって分子状の酸素 の添加はおこらない。

\section{$2 \cdot 3$ 芳香族炭化水素の酸化}

芳香族炭化水素は鎖状炭化水素に比較して, 微生 物により酸化されにくく，したがって単なる炭基源 としての発酵生産への利用といら観点から見た場合 メリットは少ないと考えられるが, その構造と種類およ び代謝経路が多様であることから，何か新しくておもし ろい発酵生産物が発見される叮能性があり, 注目されて いる研究対象の一つである。

芳香族化合物は種類が多く, またその代謝経路は微生 物の種類によっても異なるので，本文ではそれらのいく つかの例について記述することにとどめる。

微生物による芳香族炭化水素の代謝に関しては van

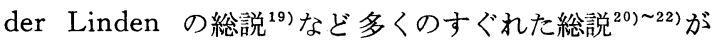
あるので興味のある読者はそれらを参照されたい。

\section{$2 \cdot 3 \cdot 1$ ベンゼン}

ベンゼンはカテコールにまで酸化された後環が開裂し 代謝されるが，カテコールへ至る経路に関してまだ不明 な点が多い。図-5 にベンゼンの酸化経路を示す。ベン ゼン資化性菌としては Pseudomonas aeruginosa ${ }^{23)}, P$. putida $^{24)}$, Mycobacterium rhodochrous ${ }^{25)}$, Micrococcus sphaeroides ${ }^{23)}$, Nocardia sp. ${ }^{25)}$ などが知られ

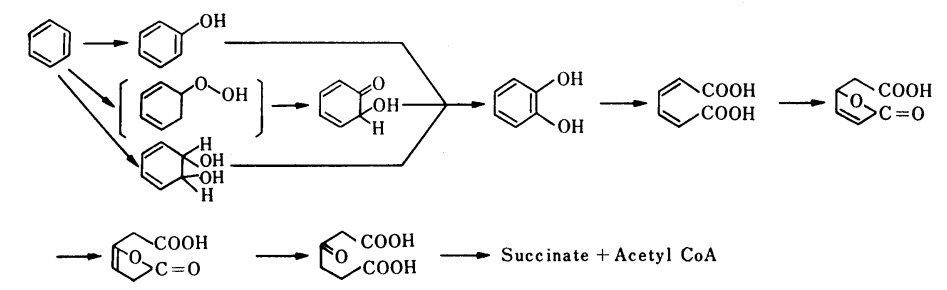

図-5 ベンゼンの代謝経路

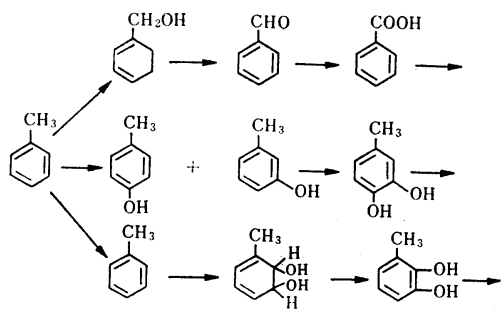

图-6 トルエン酸化し推它経路 
ている。

$2 \cdot 3 \cdot 2$ トルエン

トルエンの酸化経路としては $P$. aeruginos $a^{26)}, P$. putid $^{27)}$ などの菌を用いて図-6に示すような経路が 推定されている。

$2 \cdot 3 \cdot 3$ アルキルベンゼン

$n$-アルキルベンゼンの酸化は，まず側鎖のアルキル基 が酸化を受け，ついで環の開裂がおこるが，代謝中間体 としてベンゼン核を有する種々の有機酸が生成してく る。これらの有機酸は側鎖のCの数が奇数か偶数かによ って異なっている。またCの数が 2〜5 の場合, 単一基 質として微生物を培養し有機酸の生成を報告した例はな

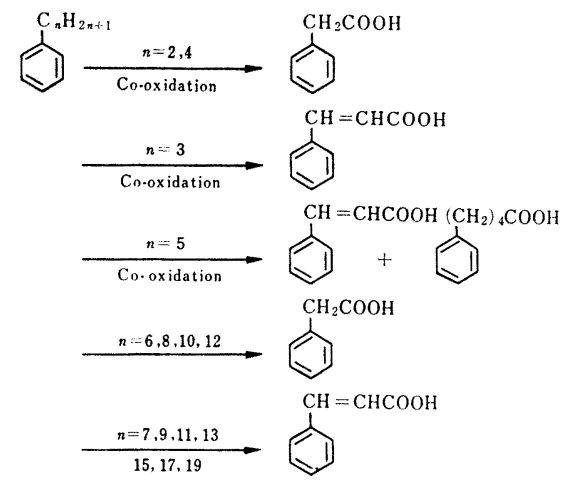

図-7 アルキルベンゼンの酸化 22

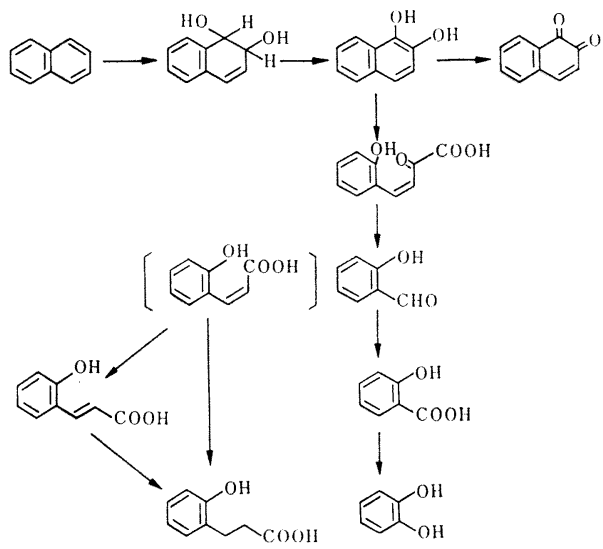

図-8 ナフタリンの酸化 ${ }^{22}$
く，Co-oxidation によってこれらの基貿の酸化が行な われる。Co-oxidation とは単独では酸化を受けない化 合物が微生物の生育基質を共存させることにより酸化さ れる現象をいう。

図-7 にアルキルベンゼンの酸化生成物をまとめる。

$2 \cdot 3 \cdot 4$ ナフタリン

ナフタリンは Pseudomonas aeruginosa, Nocardia, Bacillns 属の細菌などによって酸化分解される。酸化 経路としては図-8 に示すように 1,2-dihydroxynaphthalene を経て環が開裂し，サリチル朘，カテコールを 経て TCA サイクルに入るという経路が提示されてい る。

\section{3 発酵生産物について}

はじめに述べたよらに gas oil からの菌体生産に関 する研究を契機として始まった石油発酵は日本において 各種の発酵へ忘用され，グルタミン酸をはじめとする各 種アミノ酸, 核酸関連物質, 有機酸, 脂肪酸, ビタミ ン, 抗生物質, 糖類など多くの発酵生産物が得られ, そ の中のあるものは工業的な段階まで研究が進んでいる。 これら各種発酵生産物については多くのすぐれた総説が 書かれているので本文では工業的に有望と考えられてい る生産物について簡単に記述したい。

\section{$3 \cdot 1$ 菌体の生産}

微生物菌体の生産の目的はおもにタンパク質源の確保 にあるが，菌体はタンパク質のほか, 脂質, 炭水化物,

ミネラル, ビタミンその他微量要素を含み，栄養的にも 相当な価傎があるといえよう。しかしながら核酸含量が かなり多いことや消化率の悪さあるいは安全性の問題な ど克服すべき問題点が残っており, 今後の地道な研究が ますます望まれる。

炭化水素を原料とする菌体生産菌には, 酵母では Candida 属, 細菌では Pseudomonas 属に優秀な菌が 多い。またメ夕ノール資化性菌としてはKloeckera sp. Torulopsis methanovascense, T. glabrata, Candida methanolica, Pseudomonas sp. などが得られている が，現在工業的に使用されようとしている菌は酵母であ る。表-1 および表-2 に生座菌の代表例を一覧する。

これらの表から微生物の生産性 (productivity) は他

表-1 生産菌 の代表例

\begin{tabular}{|c|c|c|c|c|c|c|c|}
\hline 名 & 基 & 質 & 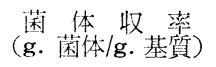 & \multicolumn{2}{|c|}{$\begin{array}{c}\text { 比增殖速度 }\left(\mathrm{hr}^{-1}\right) \\
\text { (doubling time, } \mathrm{hr} \text { ) }\end{array}$} & $\begin{array}{c}\text { 粗タンパク芌量 } \\
(\%)\end{array}$ & \\
\hline Candida lipolytica & nーパラフィ & イン & $0.85 \sim 1.0$ & $0.2 \sim 0.35$ & $(3.5 \sim 2)$ & $47 \sim 60$ & $(28)(29)$ \\
\hline Candida petrophilum & " & & 1.0 & 0.32 & $(2.2)$ & $50 \sim 56$ & $(30)$ \\
\hline Micrococcus cerificans & " & & $1.1 \sim 1.3$ & $0.7 \sim 0.9$ & $(1 \sim 0.8)$ & $\cdots$ & $(31)$ \\
\hline Mixed culture (Bacteria) & 3 & ン & $0.6 \sim 0.7$ & $0.11 \sim 0.198$ & $(6.3 \sim 3.5)$ & & $(32)$ \\
\hline Torulopsis glabrata & ×夕人一 & ール & 0.57 & 0.19 & $(3.6)$ & $\cdots$ & (33) \\
\hline Pseudomonas sp. & " & & 0.52 & 0.52 & $(1.3)$ & 86.5 & (34) \\
\hline
\end{tabular}


表-2 微生物菌体の化学成分と必スアミノ酸組成*

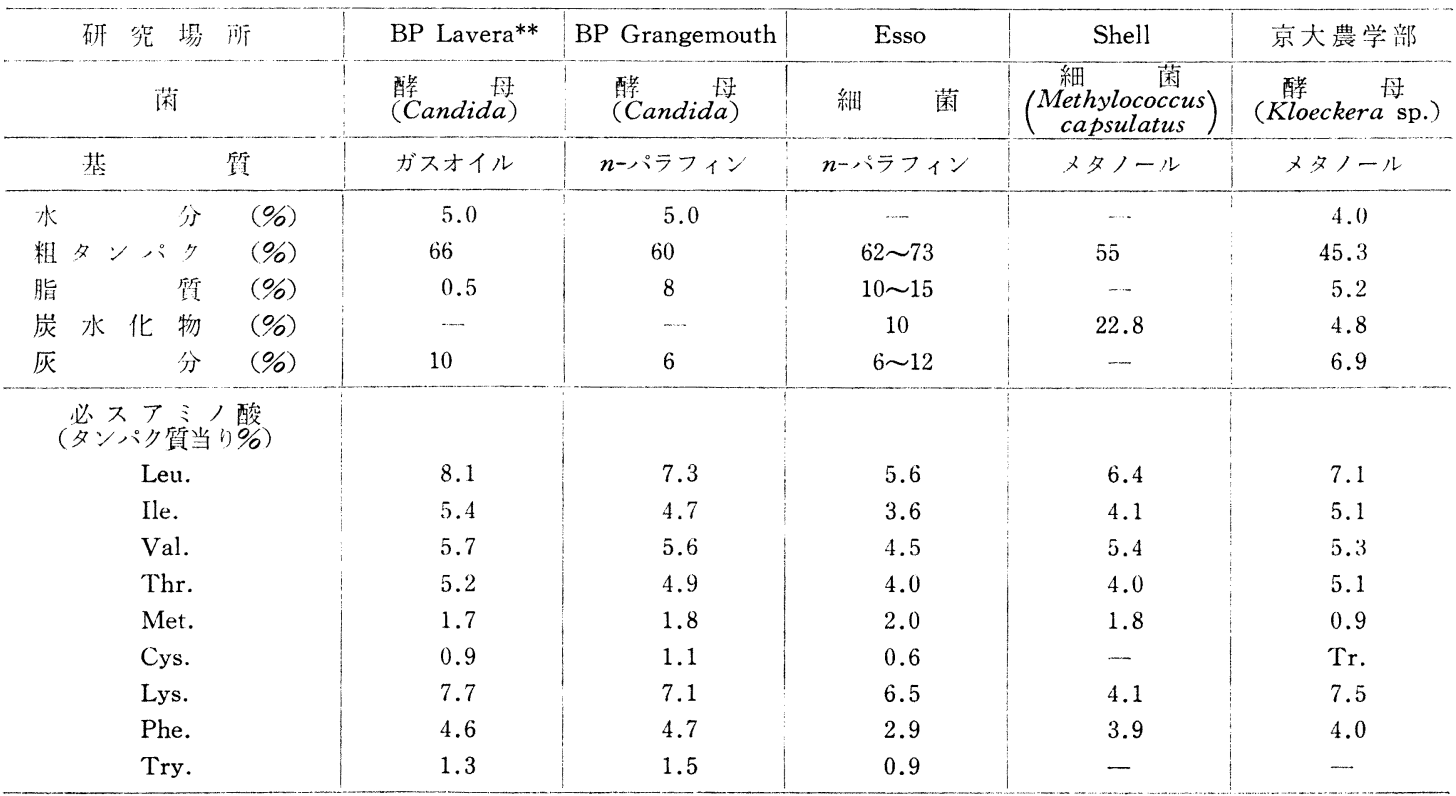

* 山田浩一, 石油と石油化学，12，41（1968）から引用した表にいくらか書き加えた。

** ヘキサンで洗浄した菌体

の生物に比べて著しく大きいことがわかるであろう。な お種々の生物の增殖率（基準として重量が 2 倍になる時 間をとる) はカビ，クロレラで $2.0 \sim 6.0 \mathrm{hr}$, 高等植物 で $144 \sim 288 \mathrm{hr}$ ，ニワトリで $288 \sim 576 \mathrm{hr}$, ブタ, ウシで $672 \sim 1,440 \mathrm{hr}$ といわれている。

\section{2 アミノ酸の生産 ${ }^{35}$}

現在，L-グルタミン酸，L-リシン，L-スレオニンな ど多くのアミノ酸が発酵法によって工業生産され, 発酵 工業に扔ける一大部門を占めている。

炭化水素からアミノ酸を生産しょらとする試みは, 山 罒，飯塚らの両研究グループにより，まず L-グルタミ ン酸を蓄積させることから開 始され，現在ではほとんどの アミノ酸が炭化水素から生産 されることが明らかになって いる。収量についても研究初 期のころに比較すると飛躍的 に増加し， L-グルタミン酸 は $84 \mathrm{~g} / l$ (対基質収率 84\%) と著しく高収量で得られるよ らになった。

また炭化水素からばかりで なく, エタノールやメタノー ルなどの低級アルコール類か らも $\mathrm{L}$ クグルタミン酸は著量 生成する。

このような石油発醳による
アミノ酸生産の淮展は, 従来の糖質利用のアミノ酸発酵 に扔ける経験を背景にして生まれたものである。L-グル タミン酸発酵を例にして考えてみると,ペニシリン添加, 脂肪酸および界面活性剤の添加あるいは変異株の取得な ぞ従来の経験が綐横に駆使され, 収量の増加や発酵時間 の短縮など好結果が得られている。しかしながら，炭化 水素利用のアミノ酸生産は糖質や酶酸を原料とした場合 に比較し，発酵時間が長くまた生産物の回収に問題点が あるために工業化までにはいたっていない。

表-3 炭化水素から生産されるアミノ酸を示す。

\section{$3 \cdot 3$ 有機酸の生産}

表-3 炭化水素からのアミノ酸の生産

\begin{tabular}{|c|c|c|c|}
\hline$r ミ$, 酸 & 炭 素 源 & 収 量 $(\mathrm{g} / \mathrm{l})$ & 産 \\
\hline L-グルミミン酸 & $\begin{array}{l}\text { グルコース } \\
\text { 酢 酸 } \\
\text { エタノール } \\
\text { メタノール } \\
\text { 安息香酸 } \\
n \text {-パラフィン }\end{array}$ & $\begin{array}{c}50 \sim 100 \\
70 \sim 100 \\
(50 \%) \\
59 \quad(66 \%) \\
10.5(11 \%) \\
80 \quad(80 \%) \\
84 \quad(84 \%)\end{array}$ & $\begin{array}{l}\text { Brev., Arth., Cory. } \\
\text { Brevibacterium etc. } \\
\text { Brev. sp. } \\
\text { Methanomonas methylovora } \\
\text { Brevibacterium sp. } \\
\text { Cory. hydrocarboclastus } \\
\text { (Penicillin resistant) }\end{array}$ \\
\hline$L-リ$ & $n$ nー゚ラフィン & $34 \quad(34 \%)$ & Nocardia sp. \\
\hline$L-ト V A=v$ & " & 15 & Arthrobacter paraffineus \\
\hline L-イソロイシン & $"$ & 1.6 & Micrococcus paraffinolyticus \\
\hline Lーホモセリン & " & 12 & Corynebacterium sp. (Thr. 要求株) \\
\hline L-チトルリン & " & 9.5 & Arth. paraffineus (Arg. 要求株) \\
\hline L-チ ロ シ ン & " & 18 & Arth. paraffineus (Phe. 要求株) \\
\hline $\mathrm{L}$-フェニルアラニン & $n$ & 15 & Arth. parafflineus (Tyr. 要求株) \\
\hline
\end{tabular}




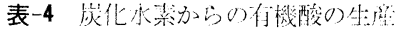

\begin{tabular}{|c|c|c|}
\hline 存機酸 & 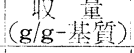 & 闲 \\
\hline \multirow[t]{3}{*}{ "エン酸 } & $\begin{array}{l}0.56 \\
(28 \mathrm{~g} / l)\end{array}$ & Arthrobacter paraffineus ${ }^{36)}$ \\
\hline & $\begin{array}{c}1.40 \\
(84 \mathrm{~g} / l)\end{array}$ & C'andida li polytica ${ }^{3 i)}$ \\
\hline & $1.05 \sim 1.18$ & Penicillium janthinellum ${ }^{38)}$ \\
\hline \multirow{2}{*}{$\begin{array}{l}\text { ホーケトグル } \\
\text { タル陵 }\end{array}$} & 0.86 & \multirow{2}{*}{$\begin{array}{l}\text { Corynebacterium } \mathrm{sp}^{38)} \\
\text { Candida lipolytica }{ }^{30)}\end{array}$} \\
\hline & 0.9 & \\
\hline 二八ク変 & $23.6 \mathrm{~g} / \mathrm{l}$ & Candida brumptii $i^{41}$ \\
\hline フマル酸 & 0.84 & Candida hydrocarbo fumaric ${ }^{42)}$ \\
\hline はーリンン゙稜 & 0.7 & $\begin{array}{l}\text { Candida hydrocarbof fumarica }{ }^{43)} \\
+\left\{\begin{array}{l}\text { Candida utilis } \\
\text { or Pichia membranaef aciens }\end{array}\right.\end{array}$ \\
\hline & $13 \mathrm{~g} / \mathrm{l}$ & Candida brumptii ${ }^{44)}$ \\
\hline
\end{tabular}

鋇状炭化水素から生産される有機酸はほとんど TCA 问路上の有機酸に限定されている。これまでに著翼蓄櫴 に成功したもの上しては，表-4に示すようにクエン酸，

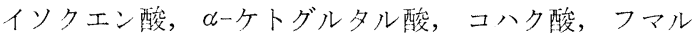
酸，リンゴ酸がある。また芳香族炭化水素からも種々の 有機酸が生座される。たとえばナフタリンからサリチル 䐗，pーキシレンからpートルイル酸，p-シメンからクミ ン酸，アルキルベンゼンからケイ皮酸，フェニル酢酸な よ゙が報告されている。

以上の有機酸の中で最も工業化の问能性の強いクエン 酸について略述する。

クエン酸は果実やソ菜中に広く分布し, 酸味の主体を なすもので, 主に清涼飲料水, 果実カン詰などの酸味剂 として使用されている。現在，その生産量は世界で年間 10 万 $\mathrm{t}$, 日本で約 $7,500 \mathrm{t}$ に達し，発酵工業に拈いては 生産量の多いものの一つである。

クエン酸はキレートカが強いので, 洗剂ビルダー用に 使用されているトリポリリン酸ナトリウムの代替物とし ての用途が期待されており，さらに排煙中の亜硫酸ガス を除亡するための吸脱着剤としての用途も考えられてい る。もしそのような新用途が開発されれば，クエン酸の 生産荲は飛躍的に増大するであるら。

岑化水素からクエン酸が著量生成することを最初に見 いだしたのは田渕ら ${ }^{37}$ である。使用した菌はCandida lipolytica であった。その後多くの菌がクエン酸を蓄積 するこ上が明らかにされ，また生産量も飛躍的に増大し た。酵母を用いた場合にはイソクエン酸が副生してくる が，イソクエン酸の副生はクエン酸の収量を低下させる ばかりでなく，クエン酸の回収精製を妨害するのででき るだけ低レベルに抑えなければならない。

田㴊らは培地中の鉄イオン濃度を低く保つことにより イソクエン酸の副生を抑制したが ${ }^{45)}$ ，実際の発酵生産に おいて鉄イオン濃度を $1 \mathrm{ppm}$ 以下に制御することはは なはだ困難である。またアコニターゼの阻害剤であるモ

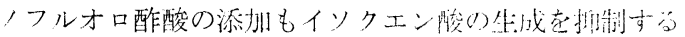
が，クエン酸が食品添加戍として使用されることを考隹 すれば，このような阻害剂を使うことは好ましくない。 そこで，この問題を解沈するために秋川汴 ${ }^{46)}$ はアコニタ 一ゼ活性の弱い変異林を誘導することを新み，イソクエ ン酸の副生を抑制することにみごとに成功した。

\section{4 脂肪酸の生産}

炭化水素の特徵を生汃した発酵生裹物としては鎖状炭 化水素からの脂肪陖および芳香族炭化水素からの各種有 機酸がある。これまでに得られている脂肪酸にはモノカ

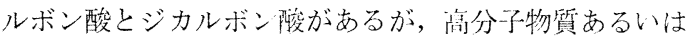
香料の原料としての胢途がある戊銧ジカルボン凌の微生 物による著是蓄積は注目に俌する。

ジカルボン酸は先にも述バたようにクーハラフィンの diterminal oxidationにより生成される。最初 Foster によって Corynebacterium 渪の細菌がジカルボン酸を かなり蓄積することが報答された ${ }^{4 i}$ 。冬の㣪内尾ら ${ }^{48)}$ よって精力的に研究が淮められ，Candida高の酵母が 原料炭化水素に対応するジカルボン酸を生应することが 明らかにされた。さらに，かれらは優秀な生产菌である Candida cloacae 310 よりジカルボン睃资化能欠損变 異株および $n$-アルカン盗化能欠損变異株を誘導し, 種々 の培養条件の検封の結果, $n$-ヘキサデカン $10 \%(\mathrm{vol} / \mathrm{vol})$ より最滈 $55.2 \mathrm{~g} / \mathrm{l}$ の $\mathrm{C}_{16}$-ジカルボン䶼を得た。

以上，現在工業的に润能性の女る発酳生座物につい下 簡拼に述心゙たが，抗生物質などの生理活性物筫，ビタミ ン，核酸およびその関連物塤など興味ある発酵生座物が

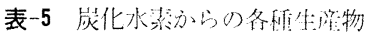

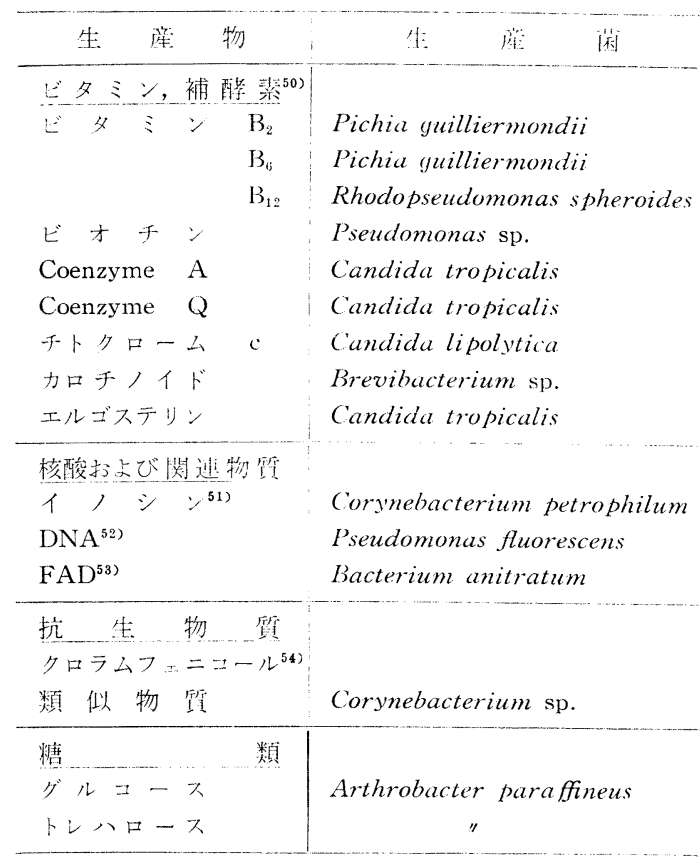


次々に胃いだされておうり，今後の研究が㧍扔いに期待さ れる。表-5 亿種々の登醳生産物を一覧する。

\section{4 微生物による炭化水素の取込み 機構へのアプローチ}

炭素数が 10 以上の比較的鎖の長い $n$-パラフィンの 微生物による取込み問題について述べる。

$\mathrm{C}_{10}$ 以上:の n - パラフィンは水にほとんど不溶性であ るために, その取众み㥞式は糖質などの水溶性基質の埸 合と異な一ていると考えられ, 培養上種々の問題を提供 寸る。态用的には基質炭化水素の微生物一の取迄み速度 が微生物の生育の律速段階にならなければ良いのであ。 て,nーパラフィンをいかにしてよく分散させるか，また どの程度まで分散させれば良いかなどが当闻の閭題とし てとり上げられてきた。

炭化水素を乳化分散させる方法としてはかくはんなど による機械的分散法と界洦活性剂添加による分散法があ るが, 界泊活性剤の添加は菌の種類によってはむしろ阻 害的に働く場合も多く，またコストの洎からも望ましく ない。そこで機械的かくはんと炭化水素の分散および微 生物の生青の関倸を知ることが重要とな⿰てくる。一方 炭化水素凟化性菌は菌自身が炭化水素を乳化する力を 持っていることが観察されて扔り，脚なる工学的なアプ ローチのみではこの闆題の解明は困難であるう。

まず微生物により 取り込まれる際の㸚 化水素の状態につい て考察してみよう。 これまでに提穼さ れた仮説を整理して みると図-9 に示す ようなうつの考え方 がある。

第 1 の見解は水汇 溶解した炭化水素の
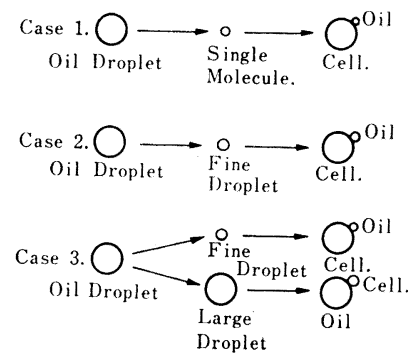

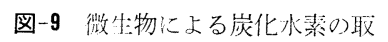
込々纪関与る作業仮説
取込みが支配的であるといら説で，この説は炭化水素の 溶解度の点から否定的である。

McAuliffe ${ }^{55}$ のデータを用いて計算すると $n$-dodecane 以上の炭化水素の溶解度は $10^{-2} \mathrm{mg} / l$ 以下である。

Johnson $^{56)}$ は炭化水素の溶解度が 小さいことを考虑 して次のような考察をしている。炭化水素資化性菌の炭 化水素に対寸る親和性が強い（ミ八エリス常数が非常に 小さい）ならば基質の溶解度が小さくても充分な生育が 期待できるが，たとえミハエリス常数が 0 であっても抗 散現象の律速を受けるので，実際の培養でみられるよう な生育は望めない。このような理由をもって第1の見解 を否定した。Humphery ${ }^{57}$ もまた同稼な見解を述べて おり, さらに合葉ら ${ }^{58}$ はいくつかの仮定の下に数值計算
を行ない，水に溶解した炭化水素のみを利用して生充し た菌の炭化水素消費量は全量の $0.9 \%$ を越えないことを 示し, Johnson や Humphrey の説を支持した。

垷在では炭化水素の取远みは炭化水素油滴と菌の直接 接触によ，て行なわれる，すなわち図-9 の case 1 上 case 2 の場合が支配的であろらと考えられている。し かしながら case 1 上 case 2 のどちらが支配的である かについてはまだ不明な点が多く今後の問題であるが， この点に関しては菌の性:質が密接に関倸しており, 菌の 種類によってそれぞ机璂なっているとものと思わ机る。

たとえば Candida guilliermondii では accomodation 状態の油滴 (長㭙間放置しても水から分離せず, 光学顕微鏡では判別できない程の微小油滴）が利用され るであろうと考察されており，またCandida petrophilum では菌が油滴のまわりに付着し, flock 状態を形 成しているときに生育が速いという観察 ${ }^{59}$ から, かなり 大きな油滴もよく利用されると推論されている, Bakhuis ら ${ }^{(0)}$ は colloid mill を用いて種々の平均粒径を有する 乳化基質を調整し, Candida tropicalis について調心゙ た結果, 油滴の平均粒径が 20 25 最低になることを認就た。

著者らが使用している菌，Pseudomonas aeruginosa $\mathrm{S}_{7} \mathrm{~B}_{1}$ は case 2 の垗合, 寸なわち微小油滴が菌に上。 て最適である場合に性当するょうであり，いくつかの興 味ある現象も見いだされているので，本菌について以卜 に簡単に述べてみたい。

著者らは菌体生産菌として土壦より分皠された $I$. aeruginosa $\mathrm{S}_{7} \mathrm{~B}_{1}$ が界面活性剂の添加によって生育が著 しく促進されることを垫め, また菌の表面状態が比較的 親水性であることを観察した ${ }^{61)}$ このことから本菌が炭 化水素油滴を利用する場合, できるだけ接触面積が大き くなるよらに菌自身が何か乳化物質を分泌している川能 性があると考えた。この考えに基づいて人塚ら ${ }^{(2),(i 3)}$ 本菌の培養液から界渵活性力を有しかつ菌の生育を促淮 させ, また呼吸活性を増加させるような物質を検索し, 糖脂質である rhamnolipid とタンパク犋様の蓓分子物 質を単灕精製した。

rhamnolipid は図-10 に示すように rhamnose 2 分

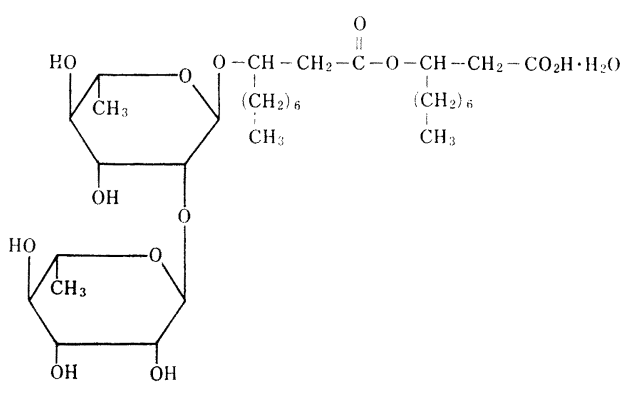

図-10 Rhamnolipid の㩐造 
子と $\beta$-hydroxy decanoic acid 2 分子から構成されて おり, 本物質の添加効果は Pseudomonas aeruginosa に特異的で，またグルコースや脂肪酸を基質にした場合 は見られず，炭化水素を基質にしたときのみ著しかっ た。したがって rhamnolipid の添加効果は炭化水素の ような難溶性基質の場合のみに特翼的に見られる現象で あると考えられる。

rhamnolipid はまた強い乳化力を有し, そのエマル ションは非常に安定であった。

さらに超音波処理によってあらかじめ乳化した基質を 用いた実験の結果から, rhamnolipid の添加効果はそ の乳化作用に基-゙くものであり, 炭化水素一水界面の界 面面積を広げるばかりでなく, 炭化水素油滴のサイズを 小さくするためであろうと考察している。

このような乳化力を有する糖脂質は表-6 に示すよう に rhamnolipid 以外にも二, 三単離されている。

表-6 微生物により生成される乳化物質 ${ }^{54)}$

\begin{tabular}{c|c|c}
\hline 乳化物 犋 & 菌 & 文 \\
\hline Trehalose lipid & $\begin{array}{l}\text { Arthrobacter } \\
\text { Brevibacterium } \\
\text { Nocardia etc. }\end{array}$ & $\begin{array}{c}\text { T. Suzuki et al. } \\
(1969)\end{array}$ \\
\hline Sophorose lipid & $\begin{array}{c}\text { Torulopsis } \\
\text { magnoliae }\end{array}$ & $\begin{array}{c}\text { A.P. Tulloch et } \\
\text { al. (1962) } \\
\text { D.F. Jones et } \\
\text { al. (1968) }\end{array}$ \\
\hline Rhamnolipid & P. aropengiesseri & $\begin{array}{c}\text { K. Hisatsuka et } \\
\text { al. (1971) }\end{array}$ \\
\hline Peptide lipid & $\begin{array}{c}\text { Candida } \\
\text { petrophilum }\end{array}$ & $\begin{array}{c}\text { T. Iguchi et al. } \\
(1969)\end{array}$ \\
\hline
\end{tabular}

次にタンパク様高分子物質についてであるが，本物質 は rhamnolipid の呼吸活性に対する作用を調べている 間に新たに培養液中から呼吸活性を促進する物質として 分離されたもので, 硫酸アンモニウム塩析, 各種クロマ トグラフィーにより単離精製され, 種々の呈色反応, UV 吸収スペクトル，アミノ酸分析，熱安定性などの結果か ら本物質がタンパク質であることが明らかにされた。

本物質もまた図-11 に見られるように，炭化水素を基 質とした場合にのみ特巽的な効果をもち, rhamnolipid との間に相乗的な交互作用がある。

本物質の作用のメカニズムはまだ不明な点が多いが, EDTA によって処理された $P$. aeruginosa の呼吸活 性と rhamnolipid および本物質の添加勃果の検討から， 本物質が炭化水素油滴を $0.22 \mu$ 以下に細粒化している ことが推定された。

余語ら ${ }^{64)}$ はあらかじめふるい分け油滴径をある程度そ ろえたワックスエマルションを調整し, 油滴径と $P$. aeruginosa の呼吸活性との関係を調心゙，油滴径が小さ いほど基質として利用されやすいことを認めた。これら

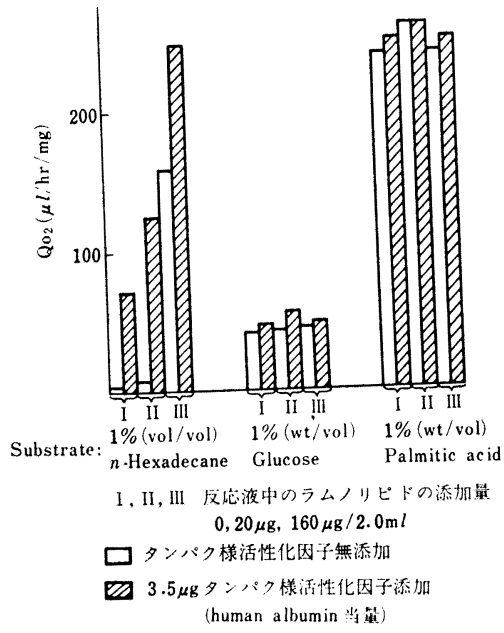

図-11 各種基質の酸化に刘する精製タンパク様 活性化因子の影響

の結果から P. aeruginosaにおいては油滴径が小さい方 が利用されやすく, 油滴径を小さくするために rhamnolipid やタンパク様高分子物質を分泌していることが考 察される。

\section{5 おわりに}

石油発酵について応用的および基礎的な両面から略述 してきたが，これから解明していかなければならない問 題点が山積していることを痛感する。今後, 界面化学, 油脂関係の研究にたずさわっている研究者の協力を得て 本分野の研究がますます進展することを望みたい。

（啊和 48 年 9 月 11 日受理）

\section{文献}

1) A. Champagnat, C. Vermet., B. Laine, J. Filosa., Nature, 197, 13 (1963)

2）石油醴酵研究会編 “石油酰䣼”, (1970), 幸書房, 東京

3）植村，相田編，“発醉と徽生物”第 III 巻，(1971), 朝倉 書店, 東京

4) J.B. Davis, "Petroleum Microbiology", (1967), Elsevier Publishing Co.

5) R. Uchio, I. Shiio, Agr. Biol. Chem., 36, 426(1972)

6) A.S. Kester, J.W. Foster, J. Bact., 85, 859 (1973)

7) M.Y. Ali Khan, A.N. Hall, D.S. Robinson, Nature, 198, 289 (1963)

8）山田，鳥越，農化，40，364（1966）

9) M. Dworkin, J.W. Foster, J. Bact., 72, 646 (1956)

10) H.B. Lukins, J.W. Foster, J. Bact, 85, 1074 (1963)

11) J.R. Vestal, J.J. Perry, J. Bact., 99, 216 (1969)

12）石油酰酵研究会編 “石油酰酝” p. 298 (1970), 幸書房, 東京

13) D.A. Klein, F.A. Henning, Appl. Microbiol., 17, 676 (1969)

14) M.J. Klug, A.J. Markovetz, J. Bact., 93, 1847(1967)

15) J.A. Peterson, M. Kusunose, E. Kusunose, M.J. Coon, J. Biol. Chem., 242, 4334 (1967)

16) M. Kusunose, E. Kusunose, M.J. Coon, J. Biol. Chem., 239, 1374 (1964) 
17) J. Chouteau, E. Azoulay, J.C. Senez, Nature, 194, 576 (1962)

18）飯明，飯塚，醗工, 47, 442 (1969)

19) A.C. van der Linden, G.J.E. Thijsse, Adv. Enzymol., 27, 469 (1965)

20) E.J. McKenna, R.E. Kallio Ann. Rev. Microbiol., 19, 18 (1965)

21）小林，山田，醗劦誌， 21，453 (1963)

22）大森, 石油と微生物，(5), 10 (1971)

23) E.K. Marr, R.W. Stone, J. Bact, 81, 425 (1961)

24) D.T. Gibson, J.R. Koch, R.E. Kallio, Biochem., 7, 2653 (1968)

25) T. Wieland, G. Griss, B. Haccius, Arch. Mikrobiol., 28, 383 (1958)

26) M. Kitagawa, J. Biochem., 43, 553 (1956)

27) D.T. Gibson, M. Hensley, H. Yoshida, T.J. Marby, Biochem., 9, 1626 (1970)

28) S.V. Chepigo et al., 7 th World Petrol. Congr., April (1967), Mexico

29) C. Gatellier, G. Glikmans, 1). Ballerini, IFP Report, No. 15038, September (1967)

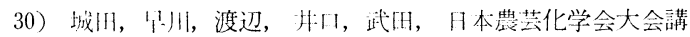
演，跑和 44 年: 4 月

31) K.R. Guenther, M.B. Perkins, South Aftrican Patent, Appl. No. 642075 (1964)

32) P.S. Vary, M.J. Johnson, Appl. Microbiol., 15, 1473 (1967)

33) H. Asthana, A.E. Humphrey, V. Moritz., Biotech. Bioeng., 13, 923 (1971)

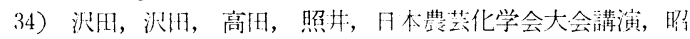
和 46 年 4 月（東京）

35）奥村，不油と徽生物，(7)，36（1972）

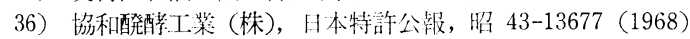

37）田湔，田中，阿部，農化，43，154（1969）

38）木村, 田中，日本㕮芸化学会大会講演，昭和 45 年 4 月 (福倜)

39）田中，木村，銿木，山口，木下，醗工， 47, 291 (1969)

40) R. Tsugawa, T. Nakase, T. Kobayashi, K. Yamashita, S. Okumura, Agr. Biol. Chem., 33, 158(1969)

41) M. Sato, T. Nakahara, K. Yamada, Agr. Biol.
Chem., 36, 1745 (1972)

42) K. Yamada, T. Furukawa, T. Nakahara, Agr. Biol. Chem., 34, 670 (1970)

43) T. Furukawa, T. Nakahara, K. Yamada, Agr. Biol. Chem., 34, 1833 (1970)

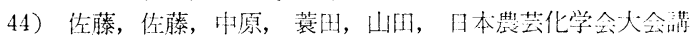
演, 眧和 48 年 4 月 (東京)

45）时渕, 由中, 田原，阿部，農化，44，562（1970）

46) S. Akiyama, T. Suzuki, Y. Sumino, Y. Nakao, H. Fukuda, Agr. Biol. Chem., 36, 339 (1972)

47) J.W. Foster, 日本特峐公告, 昭 38-15608 (1963)

48) R. Uchio, I. Shiio, Agr. Biol. Chem., 36, 1169, 1389 (1972)

49) S. Fukui, A. Tanaka, 8th World Petroleum Congress, 1971, (Moscow)

50) T. Iguchi, I. Takada, Agr. Biol. Chem., 30, 709 (1966)

51）富田，鈴不，日本農芸化学会大会講演，昭和 46 年: 4 月 (柬等)

52) 西村, 飯塚, 農化, 46, 639 (1972)

53) T. Suzuki, H. Honda, R. Katsumata, Agr. Biol. Chem., 36, 2223 (1972)

54）中原，石油之微生物，（8)，33（1972）

55) C. McAuliffe, J. Phys. Chem., 70, 1267 (1966)

56) M.J. Johnson, Chem. Ind., September 5, 1532(1964)

57) A.E. Humphrey, Biotech. Bioeng., 9, 3 (1967)

58) S. Aiba, K.L. Haung, V. Moritz, J. Someya, J. Ferment Technol., 47, 211 (1969)

59) A. Mimura, S. Watanabe, I. Takeda, J. Ferment. Technol., 49, 255 (1971)

60) E. Bakhuis, P. Bos, Antonie van Leeuwenhoek, 35, Supplement, Yeast Symposium. F 47 (1969)

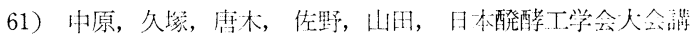
演, 昭和 44 年 11 月 (大阪)

62) K. Hisatsuka, T. Nakahara N. Sano, K. Yamada, Agr. Biol. Chem., 35, 686 (1971)

63) K. Hisatsuka, T. Nakahara, K. Yamada, Agr. Biol. Chem., 36, 1361 (1972)

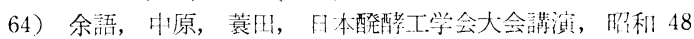
年 11 月（大阪） 